\title{
Jonatan Vinkler
}

\section{ČEŠK1 BRATJE - 560 LET 111: NA INTELEKTUALNEM ODRU ČEŠKEGA KRALJESTVA - JAN BLAHOSLAV}

Morkovice - Sližany so »mesto brez posebnosti«, majhen kraj pri Kroměřízu na jugovzhodnem Moravskem. Na prvi pogled po ničemer izstopajoč: šteje nič več kot 3000 duš. Toda ima pomenljivo zgodovino. Nanjo spominja tudi poimenovanje poljske poti, ki se še vedno imenuje Bratrská oziroma (Češko)bratska. Slížany so bili namreč v 16. stoletju eno od središč češkobratske cerkve, celo bivališče češkobratskih škofov, prav tam pa je šestindvajsetega avgusta 1557 potekala tudi sinoda čeških bratov. Na njej je bil za novega škofa izvoljen Jan Blahoslav (1523-1571; na posameznih pismih je najti tudi njegov psevdonim Apterix, po priimku matere, Katarine Bezpěrové; njegova druga psevdonima, po očetovem imenu, sta bila še Makarios in Blasius).

O Blahoslavu obstaja celo za češkega zgodovinarja obsežna in ne nujno enostavno pregledna ter obvladljiva zgodovinopisna produkcija, ki je bila izpisana $v$ zadnjem stoletju in pol ter temelji predvsem na virih v latinskem in češkem jeziku (Čejka in Šlosar 2015). Toda iz nje je mogoče razbrati vsaj dvoje: $\mathrm{z}$ Blahoslavom so češki bratje dosegli enega svojih intelektualnih vrhov, kajti po teži besedilne produkcije in njenem ključnem mestu v češki književnosti 16. stoletja so sodobniki mogli Blahoslava primerjati le z njegovim predhodnikom Lukášem Pražským, kasneje, od tolerančnega patenta Jožefa II., 1781., pa sub specie aeternitatis zgolj z zadnjim češkobratskim škofom Janom Amosom Komenským. Poleg tega so češki bratje $\mathrm{z}$ Blahoslavom postali tolikšna intelektualna sila, da je bilo treba $\mathrm{z}$ njimi računati ne le v Češkem kraljestvu, pač pa 
tudi za njegovimi mejami: s humanistom Blahoslavom so dokončno prenehali biti intelektualni »obstranci« oziroma le opazovalci v učeni kulturi in njeni sopotniki. Pomenljivo je namreč, da najpomembnejši teksti češke književnosti v drugi polovici 16. stoletja pridejo iz intelektualne delavnice čeških bratov (Blahoslav in prevajalci Biblije kralicke), utrakvistov (npr. Jiř́i Melantrich z Aventina in Daniel Adam z Veleslavína) ter evangeličanov.

Blahoslav se je rodil v Přerovu na Moravskem. Tam so bile - enako je veljalo praktično za celotno Moravsko - verske razmere in razmerja slabi dve stoletji med nastopom husitske revolucije oziroma reformacije in Belo goro, 1419-1620, občutno manj napete, blažje, strasti in razprtije pa manj silovite kot na Češkem. Přerov je namreč med 1475 in 1596 pripadal moravski plemiški družini Pernštejn, ${ }^{1} \mathrm{ki}$ je izumrla v viharnem 17. stoletju (po moški liniji 1631, po ženski 1646), v stoletju prej pa je sodila med najpomembnejše aristokratske rodove $\mathrm{v}$ deželah sv. Václava. Pernštejni so bili od začetka Husove »zadeve« pred koncilom v Konstanci (glej Vinkler 2015) odločni podporniki novega pogleda na krščanstvo, pomenljivo sled morda najpomembnejšega Pernštejna v 15. stoletju, Viljema I. (umrl 1427), pa je najti tudi na znameniti pritožbi češkega in moravskega plemstva koncilu v Konstanci zoper sežig M. Jana Husa (1515) - Pernštejnov pečat je na ohranjeni listini drugi po vrstnem redu (Hlaváček 1981, 195-203). Toda plemiška družina je bila versko strpna, razprtij zavoljo vprašanj Božjega ni iskala, poleg tega je marljive češke brate cenila kot podložnike. Tudi zato, ker so s prizadevnim delom prinašali dobiček njihovemu gospodarstvu na Moravskem. Tako so tudi češki bratje v Přerovu lahko uspevali dosti bolje kot npr. na Češkem, kjer so bili praktično ves čas v negotovem položaju ali pod naletom mestnih in/ali deželnih oblasti predvsem katoliške, občasno pa tudi utrakvistične miselne orientacije. In tako odvisni od neposredne

1 Na gradu Pernštejn v Nedvědicah na Moravskem, ki je bil matični družinski grad Pernštejnov od preloma 13. v 14. stoletje do 1596 in se danes odlikuje s sintezo poznogotske ter renesančne posvetne arhitekture, je bil posnet tudi del filma Luther (2003) z Josephom Fiennesom v naslovni vlogi (prizor prihoda Luthra pred državni zbor v Wormsu in odhoda $\mathrm{z}$ njega). 
zaščite posameznih plemiških rodov, na katerih posestih so prebivali, na primer Krajířev s Krajka.

Češki bratje so sicer v prvi tretjini 16. stoletja že dodobra premagali nelagodje pred življenjem v zgodnjenovoveški družbi, npr. v takem občestvu, kot je mesto. Posamezni radikalni glasovi so v skupnosti potihnili, zato se je izhodiščno zavračanje fevdalnega reda spremenilo v tvorno družbeno participacijo, češki bratje pa so postali eden najbolj produktivnih in prodornih družbenih delovalnikov v Češkem kraljestvu, zlasti v slovstveni kulturi. Jednota bratska je namreč ugotovila, da mora vrata med svoje člane odpreti tudi inteligenci, meščanom in celo plemičem, kot ključnim družbenim akterjem, če naj ne ostane nepomembna sekta in zato preganjana skupnost. Po drugi stani pa je ta stanovsko raznolika slika pomagala češke brate okrepiti materialno in intelektualno, Jednota pa je prav posebno energijo vlagala $\mathrm{v}$ lastno šolstvo, ki je v 16. stoletju postalo merilo dobrih šol v Češkem kraljestvu in je tako brusilo najbolj izjemne doraščajoče talente iz češkobratskih družin, ki so jih češki bratje šteli za »naslednjo generacijo« v življenju cerkve. Eden takih je bil tudi Jan Blahoslav (Škarka 1958, 151).

Blahoslav je za razliko od predhodnika in tekmeca, škofa Jana Avguste, ki je bil otrok konvertitske katoliške družine iz urbane Prage, prihajal iz češkobratskega zaledja s podeželja; tam je obiskoval tudi češkobratsko šolo. Ko so njegovi učitelji prepoznali mladeničev talent, se je Jednota odločila, da ga pošlje na študij v tujino, da bi dobil izobrazbo, ki mu jo tedaj niso mogle dati ne češkobratske šole ne Karlova univerza v Pragi; slednja češke brate ni posebej mikala zaradi verske in politične pozicije, bila je namreč branik utrakvizma. ${ }^{2}$ Pomemben in-

2 Karlova univerza se je po 1409., z odhodom treh univerzitetnih narodov (natio Polonorum, natio Saxonum, natio Bavororum) zaradi Kutnogorskega dekreta Václava IV. (1408) - z njim je češki kralj radikalno spremenil upravno podobo Karlove univerze, kot jo je določil ustanovitelj, cesar Karel IV. (en »univerzitetni narod en glas; po Kutnogorskem dekretu: češki »univerzitetni« narod trije glasovi - ostali »univerzitetni narodi« en sam glas) -, iz svetovne prelevila v zgolj regionalno zamejeno univerzo v težavah. Svojo nekdanjo univerzalnost in kvaliteto si je začela povračati šele v 16. stoletju s prihodom humanistov nanjo. Več glej v: Winter 1897, 7-18; Svatoš 2005 . 
telektualni prelom predstavlja zato zanj leto 1543 in študij na znameniti latinski šoli nemškega humanista in šolnika Valentina Trotzendorfa (Friedlanda, 1490-1556) v šlezijskem Goldbergu (Aureus Mons, Aurum, danes Złotoryja). Trotzendorf je slovel kot poznavalec grščine in izbrušen novolatinski humanist, $z$ obzorji reformacije pa se je srečal že 1518., ko se je v Wittenbergu pod Luthrovim in Melanchthonovim vodstvom posvetil teologiji ter se pri Matthäusu Hadrianu naučil hebrejščine. Med drugim je bil tudi med študenti, ki so Luthra poleti 1519 spremili na leipziško disputacijo z Andreasom Karlstadtom in Johannesom Eckom, sicer pa je bil njegov vzornik Melanchthon (Meister 1894, 661).

Jan Blahoslav se je tako pri Trotzendorfu oblikoval v smeri, ki je bila za češkobratske duhovnike dotlej komaj misljiva: njegovo delovanje je namreč temeljilo na humanistični izobrazbi v latinskem jeziku, ki je bil tedaj temeljni komunikacijski kod učene kulture - zlasti znanosti, šolstva na univerzah in diplomacije (predvsem cerkvene), znatno manj pa deželne uprave. Ker je humanistično izobrazbo povezoval z avtentično vnemo za evangelij in $z$ vero, ki da naj se po njegovem kaže v vsakdanjem pobožnem krščanskem življenju (Říčan 1951, 49), izbrušeni humanistični slog pa z retorično zmožnostjo in s prodornostjo reformiranega teologa ter biblicista, je tako poosebljal tisto, kar češki brati do njega ali sploh niso niti poskušali, ker so verskemu zanosu dajali prednost pred izobraženostjo, ali pa so zmogli le posamezniki, in še ti le z znatnim naporom in težavo - uravnovesiti fides ter intellectus pod isto streho. Zadržanje ključnih škofov je bilo namreč zastran duhovniške izobrazbe bolj ali manj odklonilno (Lukáš Pražský), kar je po stiku s češkimi brati takoj opazil tudi Martin Luther (Vinkler 2018, 84), ali pa indiferentno, npr. pri škofu Janu Avgusti, ki svojih komolcev ni kaj prida obrusil na šolskih klopeh in je lastno razmišljanje naslanjal predvsem na "zdravo pamet« in izkušnje, ki si jih je pridobil kot obrtnik - klobučar.

Blahoslav se je kot krščanski humanist torej občutno razlikoval od svojih predhodnikov. Želel je, da bi se vera v Odrešenika in pobožnost harmonično družili z najboljšo izobrazbo, ki jo je tedanja doba mogla dati kristjanu. Njegov koncept krščanskega humanizma je v ospredje stavil učenega kristjana, ki ima nalogo, da svoj razum in zmožnosti ves 
čas zavestno vednostno uri in izpopolnjuje $z$ učenjem ter znanjem. In je tako zmožen učinkovitega dialoga tudi z izobraženimi »kritiki evangelija«. Kajti talente, ki jih je prejel od Vsevišnjega, da je dobil zato, da bi jih uporabil za spoznavanje Božjih reči in za službo Božjo (Ř́čan 1951, 49), ne prvega ne drugega pa menda ne more biti brez najkvalitetnejše izobrazbe, kar jo svet v nekem trenutku premore. Toda: kristjan more, po Blahoslavovem, smisel življenja uresničiti tudi brez univerzitetne oziroma akademske izobrazbe (Molnar 1971, 208), kot je o čeških bratih zgovorno zapisal nemški humanist Joachim Camerarius st. (1500-1574) v svojem zgodovinopisnem delu Ioachimi Camerarii Pabepergensis, Historica Narratio de fratrum Orthodoxorum Ecclesiis, in Bohemia, Moravia \& Polonia. Kot krščanski ideal je Blahoslav zato postavil pobožnost v delih, umetniški okus humanista, izbrušeno besedo v latinskem in češkem jeziku - zlasti biblično besedilo je moralo biti po Blahoslavovem v službi Besede in tako drugačno, imenitnejše, povzdignjeno nad običajni govor preprostega podeželana - ter poudarek na visoki izobrazbi duhovniškega naraščaja med češkimi brati.

Topogledno se je Blahoslav najbolj razvnel v Filipiki proti misomusom (Poznamenání soudu mého o těch slovích b. Lukášových, že "nic nepsal, čehož by v Jednotě nevzal«, 18. února 1567 v Ivančicích), v kratki polemiki, ki jo je med 15. in 18. februarjem 1567 napisal kot komentar k deveti knjigi Acta Unitatis Fratrum, to jest Shromáždění pospolné těch věcí, kteréž v Jednotě bratrské a nejvíc v království Českém puosobeny sou od léta 1547 až do 1549 (gre za obsežno zbirko virov za zgodovino čeških bratov). Blahoslav je »dostavek« k pismu škofa Lukáša Pražskega pisal tako strastno, da besedilo že po rokopisnem duktusu izstopa iz siceršnje Blahoslavove zapuščine in razodeva po eni strani avtorjev virtuozni retorični domet - predvsem retorični patos humanista, toda tudi logos misleca, po drugi pa je dragocen spomenik za razumevanje napete dialektike med vabljivostjo znanja in nujo pobožnega krščanskega življenja v reformiranih cerkvah neluteranskega razvojnega toka v zgodnjenovoveški Srednji Evropi.

Filipika proti misomusom je Blahoslavov poziv na okope zoper intelektualni obskurantizem in protintelektualizem med češkimi brati. 
Oboje je skupaj z verskim fundamentalizmom v majhnih reformiranih verskih skupnostih Srednje Evrope vse od njihovega nastanka - zaradi vzpostavljanja identitete ter identifikacije na podlagi različnosti in razlikovalnosti od/do večjih cerkva, npr. rimske - morda celo neobhodni strukturni pojav, ki lahko v nekem zgodovinskem trenutku dobi protiutež le $\mathrm{z}$ vrhunskim intelektualcem ali z intelektualno vsaj s skrajno radovednim superintendentom ali škofom na čelu take cerkve.

Za kontrastivno primerjavo, ki, kot se zdi, potrjuje zapisano, kaže vzeti »cerkev slovenskega jezika« v 16. stoletju. V njej se sistematični in sistemski odpor zoper intelektualni obskurantizem razodeva predvsem skozi Trubarjevo kontinuirano programsko prizadevanje za izobrazbo krščanske gmajne, ki ga ni označevala negativna, temveč pozitivna selekcija duhovniškega naraščaja. Trubar je namreč, četudi sam ni bil univerzitetno izšolan teolog, pač pa v pretežni meri samouk, sistematično skrbel za najkvalitetnejše šolanje novih »mladic« cerkve, kot jih je imenoval. Če pustim ob strani Trubarjev besedilni leitmotiv, ki ga je v tej ali oni obliki najti praktično v vseh predgovorih $\mathrm{k}$ »uporabni literaturi« slovenske evangeličenske cerkve 16. stoletja, v katekizmih in pesmaricah, tj. da so dolžni pismeni ljudje znanje branja in knjižno snov (z glasnim branjem) širiti med nepismene, in če zanemarim tudi stanovsko šolo $\mathrm{v}$ Ljubljani, kaže poudariti, da si je Trubar po svojih najboljših močeh ves čas prizadeval, da so primerni kandidati mogli preko Tyffernove štipendije vstopiti na univerzo v Tübingenu, Jurija Dalmatina pa je izobrazbeno privedel do stopnje, godne za ustvaritev chef d'oeuvre slovenske protestantske reformacije, slovenske književnosti in jezika 16. stoletja prevoda celotnega Svetega pisma (1584).

Brez Trubarjeve izrazite intelektualne radovednosti, razgledanosti, odprtosti, razumevanja pomena visoke izobrazbe za razvoj krščanskih gmajn, izogibanja radikalnim tokovom znotraj reformacije ter prepirom zastran odprtih, toda pogosto nejasnih teoloških vprašanj (npr. okoli vprašanja prisotnosti Gospoda v zakramentu Gospodove večerje), ${ }^{3}$ pa

3 Prim. Trubarjevo pismo Heinrichu Bullingerju, Kempten, 13. marca 1557 (Trubar [1557] v Vrečko in Krajnc-Vrečko 2015, 23; celotno pismo v transkripciji in prevodu je najti na straneh 22-27). 
hkrati "posvajanja besedil« različnih miselnih provenienc (v kancionalih očeta slovenske književnosti je npr. poleg standardnega pesemskega repertorija luteranske kancionalistike najti tudi pesmi čeških bratov, pa še kakšen tekst posebej uglednega schwenckfeldijanca ali celo ozloglašenega anabaptista se najde ${ }^{4}$ bi mogel biti razvoj "cerkve slovenskega jezika« v Notranji Avstriji 16. stoletja nezamisljivo drugačen, kot je bil: Brez podmladka, izšolanega na uglednih nemških luteranskih univerzah, bi utegnil zamreti, preden se je v resnici dodobra razcvetel. - V eni sami duhovniški generaciji, in to konec šestdesetih let 16. stoletja, po izgonu Trubarja na Nemško (1565) in smrti drugega škofa evangeličanske cerkve na Slovenskem, Sebastijana Krelja (1567). - In brez nadčasnega odmeva, katerega temelj je bil položen ne le s prvo slovensko knjigo, temveč predvsem z ustvaritvijo Dalmatinovega prevoda Svetega pisma; slednjega so namreč v taki ali drugačni obliki "posvojili« tudi katoličani v obdobju baroka in je za slovenski jezik pomenil dovolj trdno sredotežno točko jezikovne podobe knjižne slovenščine, in to v času med 1599 in 1779, ko novoizdanih del ni bilo toliko, da bi se jezik in književnost dinamično (re)generirala skozi posamezne literarne žanre.

Trubar je razmerje kristjan - izobrazba verjetno najbolj sugestivno ubesedil ob vprašanju o ustanovitvi šol, v Cerkovni ordningi (1569). Le-to je deželni knez Karel II. Habsburški sicer dal zapleniti, vendar uničenje recepcije, kot je danes neizpodbitno dokazljivo tudi na podlagi memmingenskega izvoda, ki je bil v rabi pri Bernardu Steinerju, ni zaustavilo. Je pa, kot je misliti, preprečilo, da bi bila manj zamejena na zgolj duhovnike evangeličanske cerkve. Trubar je zapisal:

Obena dežela, ne meisto, ne gmaina ne mogo prez šul, prez šulariev inu prez vučenih ludy biti, ne deželskih ne duhovskih ričy prov rovnati ne obderžati. Tu vsaki zastopni človik more lahku zastopiti. Obtu nekar le samuč ty verni, Božy ludy, temuč tudi ty modri aydi so povsod v nih meistih inu deželah male inu velike šule inu $\mathrm{v}$ tih istih vučene, modre ludy deržali. [...] Potle ty kersčanski cessary, krali inu vyudi, ty so povsod collegia, cloštre, šule inu corarye za volo, de se $v$ nih vučeni inu dobre pameti hlapči-

4 Prim. Vinkler 2011, 104-107. 
či imaio koyti, rediti inu tu S. pysmu prov vučiti, zastopiti, izložiti inu pridigati, de so to cerkov, gosposke inu purgarske ričy znali inu umeli rovnati, vižati inu pelati. Obtu ie sylnu potreba tudi per sadašnim čassu, de se te šule povsod gori derže, de tei cerqvi vi dobra seimena od mladih vučenih ludy Bogu na čast inu timu kersčanstvu [k] dobrimu za sebo pustimo [poudaril J. V]. Cesary, krali, vyudi inu vsa žlaht oblast inu gosposčina so dolžni dobre, vučene šulmoištre inu umeitelne mlade ludy v te cloštre inu v corarye postaviti inu te lenee, nemarne, pozrešne, nečiste inu malikovske farye inu menihe iz nih izvreči inu izpoditi. $\mathrm{V}$ slednim meistu, $\mathrm{v}$ tergu inu per sledni fari šulmoistre inu šularie deržati, v meistih inu tergih, de se latinsku inu nemšku, per tih farah od farmoštrov, podružnikov inu mežnariev to slovensku pysmu, brane inu pissane vuči. S takim se spet ta stara, prava vera gori perpravi inu po vsem sveitu reztegne, prave, bogudopadeče Božye službe inu molitve, bruma, poštene, lubeza[n] pruti Bogu inu vmei ludmi narede, malikovane doli zatare. Inu s teim hočmo tudi te naše dežele pred Turki, pred našimi sovražniki ubraniti inu pred dragino, hudim vremeno[m], pred moryo obarovati inu ohraniti inu na koncu tiga našiga lebna dobiti tu nebesku veselie skuzi Jezusa Cristusa. H timu inu k vsakimu dobrimu dai Bug tei naši gosposčini suio milost, S. Duha, dobro missal inu napreivzetie inu dokonane. (Trubar [1564] v Vinkler 2005, 381-83)

V robni opombi je še pribil:

Sledna cerkov inu gmaina ima suie lastne šulmo[i]stre inu šularie imeiti. V niih se imaio te nucne, potrebne mladice inu flance, mladi ludy gori redyti, koyti inu vučit[i]. (Trubar [1564] v Vinkler 2005, 381-82)

Manjše reformirane cerkve odmik od vsega, domnevno, (rimsko) katoliškega, tudi visoke izobrazbe, ${ }^{5}$ po navadi zgodovinsko enačijo in občasno tudi manifestirajo s "pobožnim življenjem kristjana" in s fundamentalizmom kot distinktivnim znakom "prave vere krščanske«. V tovrstnem imaginariju in ideariju torej sovpadeta ne (dovolj) vedno oziroma nevedno in krščansko. Zdi se, da je miselno jedro takega sistem-

5 Tovrstno zadržanje je bilo značilno npr. tudi za srednjeveške katare (Lambert 200o, 172) in valdežane (Molnár 1991, 152-53; 186). 
skega obskurantizma ${ }^{6}$ kot gradnika imaginarija in idearija v reformiranih cerkvah z maloštevilnim članstvom naslednje: Pravi kristjan je lahko le bolj ali manj "preprost« osebek, kajti izobrazba je posvetnjaška reč. In ta odpeljuje od ljubega Boga in Odrešenika. In menda vsevprek kvari nedolžne duše ... Ne Blahoslav, ne Luther in tudi Primož Trubar niso menili nič podobnega. ${ }^{7}$

Genealoško je argumentacija v Filipiki proti misomusom komentar pisma, ki ga je Blahoslavov predhodnik Lukáš Pražský 17. decem-

6 Ali ne kaže morda $\mathrm{z}$ opisanim imaginarijem in idearijem tehtati tudi najnovejšo "vrnitev« škofovskega sedeža Evangeličanske cerkve AV v Sloveniji iz Ljubljane v Mursko Soboto? Zdi se, da gre za pravcato zagato: Murska Sobota z nekaj manj kot 20.000 prebivalci ali vseslovenska metropola Ljubljana z 292.988 dušami ... Nekoliko večja vas ali glavno mesto države? Ruralno in skromno ali urbano in dinamično? Morda je na tehtnici celo precej več kot le alineja v zmagovitem volilnem programu novoustoličenega škofa. Zato morebiti ni neumestno zastaviti naslednja zgolj retorična vprašanja:

- Kakšno naj bi bilo potemtakem mesto - in torej smisel - Evangeličanske cerkve kot zgodovinske dedinje ene kulturotvorno najpomembnejših epoh za slovenski narod (16. stoletje) v sodobni slovenski družbi?

- EC le za »domače«, po večini Prekmurce, ali EC kot poseben glas vere, razuma in vesti (v) »svetu«?

- Kaj pomeni »vrnitev« v komunikacijsko nepomembno podeželsko zakotje Prekmurja, ki si po kulturni, gospodarski, intelektualni in medijski dinamiki s prestolnico deli le potni list, še vremena pretežno ne? Ali morda tudi družbeno marginalizacijo EC na Slovenskem (glede na neobstoj medijske infrastrukture EC v Sloveniji)?

7 Prim. tudi poglede Primoža Trubarja in Sebastijana Krelja v pismu Adamu Bohoriču 1. avgusta 1565:

„Veleomikani mož! Ne dvomimo, da dobro poznaš in neredko obžaluješ nesrečno kulturno zaostalost naše ožje domovine, saj je prava sramota, kako se vsepovsod šopiri zaničevanje do lepih umetnosti in zanemarjanje duhovne izobrazbe. Toda ko bi le vsi, ki to bedno rovtarstvo v resnici občutijo, hoteli združiti z nami svoje želje in gorečnost, svoje misli in delo ter $\mathrm{z}$ nami vred napeti vse sile, da mu napravijo konec. Zakaj mi, ki nam je posebno jasno, da so šole cerkvi potrebne kakor leva roka, smo tej stvari že od kraja posvečali največjo skrb in prizadevnost in smo naposled $\mathrm{z}$ mnogimi prošnjami in moledovanjem pripravili prvake naše dežele do tega, da so dobrohotno in širokosrčno obljubili in določili denarno pomoč za ustanovitev javne šole tu v Ljubljani.« (Trubar [1565] v Vrečko in Krajnc-Vrečko 2015, 229; celotno pismo v transkripciji in prevodu je najti na straneh 228-29) 
bra 1502 pisal M. Havlu Žateckemu. Škof Lukaš je tej poslanici M. Havla okaral zavoljo nespoštovanja liturgične podobe češkobratske cerkve. Pražský namreč omenja Havlovo neredno branje evangelijev in listov ter opuščanje liturgičnih ur, postov, praznikov in s slednjimi povezanega cerkvenega petja (prim. Blahoslav 1861, 372). In ni pozabil poudariti, da so se češki bratje od (liturgičnega) reda v katoliški cerkvi oddaljili v tem, »kar je slabega, in ne v onem, kar se more ob dobrem namenu in čistem pomenu dobro uporabljati« (Blahoslav 1861, 372), Blahoslav pa je svojo filipiko naperil zoper tiste češke brate, ki so pismo Lukaša Pražskega razumeli kot zavrnitev vse starejše cerkvene tradicije in teološke izobrazbe, zlasti patristične in sholastične. Predvsem zoper Jana Avgusto, ki naj bi leto pred nastankom Blahoslavovega besedila govoril prav to, in proti češkobratskim duhovnikom, ki so z Avgusto soglašali; humanist Blahoslav jih je zato prikazal kot nasprotnike (visoke oziroma plemenitejše $)^{8}$ izobrazbe.

V delu Filipike proti misomusom, ki ga je mogoče brati kot vnaprejšnjo zavrnitev najpogostejših protiargumentov (refutatio), se Blahoslav retorično razživi s figurami, ki jih je že znameniti slovaški filolog in zgodovinar Pavel Josef Šafařík v 19. stoletju štel za »mojstrsko delo staročeške retorike« (Blahoslav 1861, 372):

[104r $]^{9}$ [...] Morda bo kdo rekel, da hvalim učene ljudi in učenost. Ja, tudi jaz pravim, da hvalim oboje, učenost in znanje, pa tudi izobražene ljudi, ne hvalim pa onih, ki svoje znanje rabijo za zlo. Naj dam primer: hvalimo vino in pitje ali uživanje vina, toda pijanstva in pijancev ne hvalimo. Na kratko: ne hvalimo zlorabe dobrih stvari, od Boga danih, toda abusus non tollit rem. $\left[{ }^{10}\right]$ Meč je dober, ampak nekomu more služiti za dobro, drugemu pa za zlo.

Morda boš še rekel: Preveč pripisuješ temu znanju in učenim ljudem. Res je, nekateri dobri možje pravijo, da je prav skozi učene ljudi prišlo pohujšanje v cerkev in da bi se to moglo prigoditi tudi Jednoti čeških bra-

8 Ta izraz je tedaj praktično brez izjeme označeval univerzitetni študij.

9 Segmentacija besedila je enaka, kot je v zadnji izdaji Blahoslavovega dela (2010).

1o Zloraba ne ukine same stvari[, ki je zlorabljena]. 
tov. [104v] Respondeo: $\left.{ }^{11}\right]$ Znanju in učenosti preveliko težo pripisuje tisti, kdor bi menil, da brez sedmih svobodnih umetnosti itd. ni mogoče pridigati resnice Božje, to je svetega evangelija, ali, da je od tega znanja in učenosti odvisna odrešitev. Toda kdo to pravi? Tak bi bil precej kratke pameti. Sicer se nekateri papežniki hvalijo s svojimi doktorji in drugimi učenimi možmi, čeprav so tudi pri njih bolj po redko posejani. Štejem, da je dobro in pošteno, če znanje pomaga služabnikom cerkve pri upravi, pridigarjem pa pri izvrševanju njihovega urada. Tistim, »ki so služabniki besede Božje« (kot pravi apostol), $\left.{ }^{12}\right]$ je zagotovo treba tega posebnega daru Božjega, ki ga imenujejo zgovornost, $\left.{ }^{[3]}\right]$ to je, da znajo prevajati, učiti, opominjati, karati[14] itd., kajti hudo je biti nem kot pes, in tudi prorok pravi: »Dal mi je Gospod usta izurjena, da bi razumel.«[15] Na začetku je dajal Gospod svoje darove, zgovornost, razlaganje pisem itd. svojim služabnikom tako čudežno, da se ni bilo treba tega nikomur učiti, toda ti čudeži in čudesa so prenehali. In sv. Pavel piše Timoteju: »Bodi marljiv v branju. «[16 $]$ In tako opominja, da se je treba učiti. In ker je duh Gospodov vedel, da je zgovornosti v cerkvi treba, se je tako tudi ne škodi naučiti vsakemu, kdor se lahko, in povsod, kjer je le mogoče; če kdo pričakuje, da mu bo Bog z neba s čudežem poslal zgovornost, je tako, kot bi kmet ne sejal in ne oral, ampak čakal, da bo z neba začela padati nebeška mana. [...]

[105r] [...] Kdor prezira znanje in učenost, je podoben onemu, ki bi hotel sebi in drugim sešiti krila, plašče in podobno, pa bi krojaškega poklica ne znal, se ga ne hotel naučiti, ampak bi ga sramotil in dajal v nič. Koliko bi takšen modrijan opravil? Kdo tega ne razume? Pa tisti, ki bi dal nekrojaču obleko delati in bi preziral dobre ter spretne krojače, kako bi prišel skozi? Enako kot prvi. Razen, če bi se zgodilo, da bi vsi izučeni krojači in tisti, ki so vešči tega poklica, ponoreli, podivjali ter bi začeli eden drugemu delati škodo, vsak tistemu, ki bi ga kdo hotel najeti. V takem primeru bi se moral človek obrniti drugam in se oskrbeti, kot bi vedel in znal. Iz tega se

11 Odgovarjam.

$121 \operatorname{Tim} 5,17$.

13 Lat. eloquentia.

$141 \operatorname{Tim} 4,13$.

$15 \mathrm{Iz} 50,4$.

$161 \operatorname{Tim} 4,13$. 
hitro vidi, da tistega, ki bogoslužne darove, od Boga dane in postavljene, predrzno in naduto prezira, zelo hitro kaj slabega počaka.

[106r] [...] Zato ni treba, da bi se učenih ljudi in znanja bali ter še naprej sami vezali otrobe, temveč raje prizadevno popazimo, koga in s kakšnim duhom pripuščamo k nižjim in višjim uradom, koga in kako za take službe pripravljamo, kaj imamo pri njih radi ali kaj nam ne prija ter kako smo pri tem spretni, skrbni, prizadevni in vdani Gospodu ter Jednoti. Gospod na vse gleda. Naj razsvetli naše oči, da bi ne poginili v smrtni senci.

Jan Blahoslav je svoja intelektualno in duhovno formacijo ter imaginarij humanista in privrženca reformacije okrepil tudi $z$ univerzitetnim študijem. Leto 1544 je prebil na univerzi v Wittenbergu, kjer se je seznanil z Martinom Luthrom, s Philippom Melanchthonom (Plett 1993, 109) in s klasično latinsko retoriko. Rezultat te humanistične vzgoje je predvsem delo iz zrelega obdobja Vitia concionatorum, to jest Vady kazatelìv (1571). Po vrnitvi z Nemškega in nadaljevanju študija v Prostějovu je bil poklican v središče čeških bratov Mlado Boleslav, da bi pomagal pri obnovitvi češkobratskega arhiva. Tako se je seznanil tudi z uradno in diplomatsko platjo delovanja lastne cerkve.

Toda tedaj, po juliju 1548, razmere za Jednoto na Češkem nikakor niso bile rožnate, kajti Ferdinand I. se je odločil pod pretvezo kaznovanja češkobratskih plemičev, ki so sodelovali v šmalkaldski vojni (15461547) - in izgubili -, izpuliti Jednoto iz Češkega kraljestva: menil je namreč, da je idearij čeških bratov radikalno protihabsburški. Zato bi bilo zanj zatrtje Jednote hkrati tudi ukinitev vpliva, ki so ga češki bratje v vseh stanovih že imeli na znaten del češke družbe. Tako je moral v izgnanstvo na Poljsko Jan Černý - Nigranus (150o/1510-1565), ki mu je bil Blahoslav prideljen za pomočnika pri češkobratskem arhivu in ga je imenoval tudi »ljubi oče, brat Černý«.

Blahoslav pa je po volji češkobratskih starešin spomladi 1549 odšel na novoustanovljeno univerzo Königsbergu. Le-to je zapustil že poleti istega leta, zaradi črne smrti, pa tudi verske kontroverze, ki jih je na univerzi netil Andreas Osiander st. (1498-1552), zlasti s pogledi o prežitku Kristusove opravičujoče božanske imanence v vsakem verniku, kot je 
misliti, Blahoslavu niso prijale. Bolj kot ognjeviti teolog je nanj vplival Georgius Sabinus (1508-1560), sicer prvi rektor univerze v Königsbergu in med drugim tudi Melanchthonov zet, in sicer s predavanji in spisi o pesništvu. Blahoslav je od njega dobil pobudbe zlasti za lastno teoretično in pesniško ustvarjanje. Še istega leta, jeseni, je bil Blahoslav ponovno na poti, tokrat v Basel. Tam se je seznanil z delom Erazma Rotterdamskega, predvsem pa so bili pomembni Blahoslavovi stiki s češkim humanistom Sigismundom Hrubým z Jelení - Geleniusom (1497-1554). Ta je zaslovel kot prevajalec in izdajatelj grških ter rimskih klasikov in kot njihov prevajalec v češčino (Cicero, toda tudi Petrarka in Erazen Rotterdamski), med drugim pa je bil nekaj časa tudi urednik ter korektor pri enem najznamenitejših tiskarjev svoje dobe, Johannu Frobenu (1460-1527), s katerim je Basel postal ena tiskarskih in gospodarskih metropol Evrope. ${ }^{17}$ Antonín Škarka je Blahoslavovo jezikovno izobraževanje in intelektualno formiranje povzel $\mathrm{z}$ naslednjimi besedami:

V letih, ki jih je prebil v tujini, je Blahoslav pridobil bogate življenjske izkušnje, se seznanil z metodami znanstvenega in literarnega dela na temelju humanističnih načel, hkrati pa je pod vplivom reformacije zorel kot teolog. (Škarka 1958, 152)

Humanistična latinščina, ki jo je obvladal za časa študija, mu je pomenila tudi poglavitno orodje na njegovih diplomatskih poteh. Tako je bil zastran verske svobode čeških bratov štirikrat - dvakrat 1555. in dvakrat dve leti kasneje, 1557. - poslan na Dunaj, h kralju Maksimilijanu II. Ta reformiranim kristjanom ni bil nenaklonjen, ${ }^{18}$ toda za vladanja cesarja Ferdinanda I. (Kohler 2017, 147-49, 153-58) je tudi retorično spretni Blahoslav ostal brez otipljivih rezultatov, kajti kralj Maksimilijan, če-

17 Tiski so bili v zgodnjem novem veku, zlasti inkunabule pred letom 1500, »izdelki visoke dodane vrednosti«, in torej nekaj podobnega, kot so danes produkti informacijsko-komunikacijske tehnologije (Eisenstein 1979, 44-88). Primerjaj npr. Trubarjev nemški predgovor v Ta drugi deil tiga Novega testamenta (1560). Na Trubarjeva pisma kralj, kasneje cesar Maksimilijan II. sicer ni nikoli odgovoril, je pa prizadevanje Primoža Trubarja in Ivana Ungnada podprl s 400 renskimi goldinarji (Trubar [1560] v Vrečko 2011, 71; celotni predgovor v transkripciji in prevodu je najti na straneh 59-77). 
tudi je $\mathrm{z}$ emisarjem Blahoslavom postopal prijazno in se takisto izrazil tudi o Jednoti, je mogel komaj za prihodnost obljubiti zlajšanje verskega preganjanja zoper češke brate. Neuspešna je bila tudi Blahoslavova misija 1556. v Magdeburg. Od tam je češke brate izgnal nihče drug kot čustveno in delovanjsko siloviti Flacij Ilirik. V obeh primerih je bilo stanje tako, kot je bilo pred Blahoslavovimi misijami: češke brate so v Češkem kraljestvu še naprej preganjali, pa tudi v Magdeburg se niso smeli vrniti. Je pa Blahoslav s Flacijem Ilirikom stopil v polemiko zastran izvora čeških bratov. Flacij je v spisu Catalogus testium veritatis (1556) dokazoval, da je Jednota bratrska izpeljanka valdežanov, Blahoslav pa je v svojem delu Summa quaedam brevissima collecta ex variis scriptis Fratrum (1556), ki je besedilna »druga roka« Blahoslavovega literarnega prvenca O původu Jednoty (1547), dokazoval nasprotno.

Obe deli sta temeljnega pomena za razumevanje Blahoslavovega pogleda na zgodovino oziroma, kot se je izrazil Amedeo Molnár, prihaja v njih do izraza avtorjeva »teologija zgodovine«. Blahoslav je Jednoto čeških bratov razumel kot legitimno realizacijo husitske reformacije Jednota si je ravno v letih nastajanja Acta Unitatis Fratrum prizadevala iz verske skupnosti »na obrobju « napredovati v status politično pripoznane deželne cerkve -, in torej kot posebno obliko splošne cerkve Kristusove, drugačno od luteranske cerkve na Nemškem. In takšno, ki je ravno zaradi lastne specifičnosti dolžna vztrajati pri svoji posebni krščanski poti in o tem zapustiti tudi pisne dokumente (Molnár 1971, 209). Slednje je tudi utemeljitev Blahoslavovega prizadevanja pri Acta Unitatis Fratrum.

Summa quaedam brevissima je tako Blahoslavov odgovor na vprašanje, ali so češki bratje delo Gospodove roke, kar je Flacij odločno zavračal, češki humanist pa $\mathrm{z}$ navezavo čeških bratov na intelektualno genealogijo od Husovega predhodnika Matěja z Janova (1350-1393) preko M. Jana Husa (1369-1415), M. Jakoubka ze Stř́ibra (1375-1429), Jana Rokycane (1396-1471), Martina Lupáča (umrl 1468) in Petra Chelčickega (13791460) ravno tako strastno dokazoval.

Z opozorilom na Matěja $\mathrm{z}$ Janova je Blahoslav pripoznal intelektualno genealogijo čeških bratov iz toka srednjeveške kritične misli, ki ni bila ravnodušna do aktualnih razmer v katoliški cerkvi. Ta kritici- 
zem znotraj katoliške cerkve, iz katerega sta izhodiščno črpali obe veliki evropski reformaciji - husitska in luteranska -, je občutno starejši od njiju in je »delovno orodje« katoliških teologov ter profesorjev na srednjeveških univerzah. Preko njihove univerzitetne učiteljske dejavnosti ter geografske mobilnosti (Sedlák 1996, 68-94; Šmahel 1996, 198-235) se prenaša predvsem med Oxfordom, Parizom in Prago, kjer s Husom in Jakoubkom prestopi meje univerzitetne predavalnice ter postane široko družbeno gibanje vseh stanov, tudi z nespregledljivimi političnimi posledicami.

Blahoslav je na zgodovino splošne cerkve, in tudi čeških bratov kot njenega posebnega dela, gledal kot na zaporedje manifestacij izvoljenosti, kot na pojavljanje izvoljenih posameznikov skozi zgodovino, od padca človeka iz Božje milosti do odrešitve; menil je tudi, da je imel Vsevišnji na svetu ves čas ude svoje cerkve in jih bo imel do konca stvarnosti. Četudi pravih vernikov v posameznih zgodovinskih obdobjih ni vedno lahko prepoznati med množico ljudi, pa ima ljubi Bog po Blahoslavovem na svetu vedno svoje služabnike. Blahoslav tako pravico do eksistence za češke brate ne izpeljuje iz razvoja cerkve, iz njenih izpričanih zgodovinskih strukturnih značilnosti in prelomov v zgodovinskem toku, temveč iz dejstva izvoljenosti vernikov. Gibalo zgodovine (cerkve) tako ni človek s svojimi naklepi, sklepi, spodrsi, zapleti in homatijami, temveč Bog s svojo stvariteljsko in odrešenjsko pobudo - ta da v vseh dobah zgodovine in na vseh meridianih sveta obrača kolo zgodovine in tako vedno vzdržuje svojo cerkev. Blahoslav je menil, da v posameznih obdobjih Božja cerkev ostaja skrita, anonimna, vedno pa manjšinska, in se šele s pogledom »v vzvratnem ogledalu« pokaže kot prava Božja ustanova. Tako je mogel priti tudi do na prvi pogled nenavadne, vendar ne tudi nerazložljive zgodovinske genealogije. V njej je češke brate ugledal kot duhovne naslednike Polikarpa, Ireneja, Justina, Tertulijana, pa tudi Bernarda s Clairvauxa, Roberta Grossetesteja, Francesca Petrarke, Savonarole, Jana Milíča s Kroměříža ter nazadnje Husa, Luthra in Lukáša Pražskega (Molnár 1971, 211).

Ne glede na svoje oblikovanje na protestantskih univerzah je bila Blahoslavova identiteta jasna - bil in ostal je češki brat, leta 1558 pa je 
napisal tudi polemično delo, ki je ostalo v rokopisu, in sicer z naslovom Sepsání o rozdíle Jednoty bratrské od luteriánské.

$\mathrm{V}$ njem je podobnosti in razlike med češkimi brati ter luterani strnil v naslednjih artikulih:

Tvoje vprašanje je bilo, ali so češki bratje, ki jim nekateri pravijo tudi valdežani, drugi pikarti in spet tretji Boleslavski, različica luteranov ali evangeličanov, kajti posamezniki govorijo, da se od slednjih nič ne razlikujejo ter da so vsi eno in isto.

Treba je odgovoriti, da se luterani od čeških bratov v posameznih rečeh razlikujejo, v drugih pa ne. [...]

Češki bratje in luterani so eno[tni] v naslednjem. Oboji:

1) so se ločili od rimske cerkve;

2) se držijo Svetega pisma in zgledov stare cerkve;

3) za oboje je poglavitna človekova vest in ne posameznikova dela, pač pa oboji stavijo na samem Jezusu Kristusu;

4) ljudi opominjajo k pobožnemu in častnemu življenju;

5) ljudi ne obračajo k vicam, temveč h Gospodu Kristusu in v nebesa.

Razlika med njimi pa je $\mathrm{v}$ duhovništvu ali duhovnih upraviteljih, in sicer:

1) Razlikujeta se imenovanje v urad in priprava nanj;

2) Eni so po redu podložni svojim starešinam, drugi pa imajo svobodo;

3) Prvi se s svojega mesta ne morejo premakniti brez ukaza svojih starešin, za druge pa velja običaj, da si lahko sami izbirajo mesta za službo, tukaj ali drugje;

4) V Jednoti bratski gmajne upravljajo starešine, medtem ko jih med luterani posvetna oblast;

5) Luteranski duhovniki imajo svobodo, da se poročijo, kjer in kadar se želijo, duhovniki čeških bratov pa ne, razen na privolitev in nasvet starešin;

6) Kazen med češkimi brati zadene prav vsakega, tudi duhovnike, če se v čem pregrešijo, toda pri luteranih je drugače;

7) Desetine češki bratje ne jemljejo, luteranski duhovniki pa bi težko živeli brez nje; 
8) Razlika je v vodenju in skrbi za ljudi. Češki bratje služijo v vsem, tistim pa, ki jih sprejmejo v svojo posebno skrb, služijo s prizadevnostjo, splošno in posebej, po zgledu iz Apostolskih del $20\left[{ }^{19}\right]$ njihove grehe kaznujejo, jih vodijo k popravi, učijo jih potrpežljivosti in se ne upirajo niti brezbožnim oblastem, temveč vele, da se je treba zatekati po pomoč in brambo pod Božjo roko, brez uporabe sile. Luterani pa za razliko od tega služijo brez razlike na ljudi, kaznovanje in brambo pa prepuščajo posvetni oblasti.

Po veroučni strani pa

1) se češkobratski upravitelji gmajn skupaj s starešinami držijo ene misli, medtem ko se med luterani dopušča različne poglede;

2) zastran zakramentov se, četudi se Kristusovim besedam enako veruje, pomen nekoliko različno razlaga. Toda zaradi teh razlik eden drugega ne sramotijo, če pa bi kdo na naši strani to neumestno počenjal, bi zagotovo ne utekel kazni s strani starešin, in tako se vsi skupaj trudijo za dobro, kajti o vsem je bil z Luthrom pred več kot dvajsetimi leti sklenjen prijateljski dogovor. (Molnár, Rejchrtová in Rejchrt 1977, 150-52)

V Blahoslavovi intelektualni biografiji so tri pomembna obdobja: šolanje doma in v tujini, boleslavsko in ivančicko obdobje. V prvem se je izoblikoval krščanski humanist, v drugem je začelo nastajati Blahoslavovo prevodno delo, ki ga je nato kot škof na Moravskem dodeloval. In tako ustvaril podstavo epohalnemu delu starejše češke književnosti - Bibliji kralicki. Ta ima zastran normiranja češkega knjižnega jezika, slovarja, sloga in pravopisa v stoletjih po Beli gori v češkem kulturnem miljeju povsem enako funkcijo, kot jo ima za slovenski jezik Dalmatinova biblija (prim. Breznik 1982, 28): gre za tekstno genealogijo med Novim testamentom Jana Blahoslava in Šestdelno biblijo ali Biblijo kralicko (1579-1593).

Študij v tujini je moral Blahoslav zaradi bolezni končati že spomladi 1550, zato je odtlej najprej deloval v Mladi Boleslavi, kjer je 1553. postal diakon in še istega leta češkobratski duhovnik, in nazadnje v Ivančicah na Moravskem, od 1558. Iz tega kraja je potoval le redko - na sinodo in vizitacije. Se pa je v svojem zadnjem obdobju (Ivančice) posvečal vodenju cerkve in književni dejavnosti, toda slednje je moral tu in tam začas-

19 Apd 20,19,20,27,28-31. 
no odložiti zaradi okoliščin, ki so vplivale na delovanje čeških bratov kot cerkve. To so bili predvsem notranji spori, zlasti z Janom Avgusto, mednarodni paralelogram razmerij in razmer med reformiranimi cerkvami, v katerem so češki bratje ne tako redko postali tarča preganjanja $\mathrm{z}$ evangeličanske strani, ter politična situacija $\mathrm{v}$ Reichu, ki je zaradi Habsburžanov, od 1526. voljenih na prestol sv. Václava, v Češkem kraljestvu za češke brate praviloma pomenila zaostrovanje preganjanja, zlasti z uveljavljanjem ukrepov tridentinskega koncila. Jan Blahoslav je umrl na vizitaciji v Moravskem Krumlovu 16. novembra 1571, k počitku so ga položili v podeželskih moravskih Ivančicah, toda mesto še ne petdesetletnega škofa, filologa, prevajalca, teologa, glasbenega teoretika, urednika in izdajatelja $v$ učeni kulturi njegove dobe je bila pomenljivo.

Med njegovimi stiki je najti Philippa Melanchthona, njegova zeta Casparja Peucerja (njegova prva žena Magdalena je bila Melanchthonova hči), sicer uglednega protestantskega teologa, profesorja in tudi rektorja univerze $\mathrm{v}$ Wittenbergu, učenega, toda bojevitega, celo prepirljivega Flacija Illirika in kalvinca Jana Łaskega, na dvoru kralja Maksimilijana II. pa njegovega dvornega pridigarja, evangeličana Johanna Sebastiana Pfauserja in celo kraljevega osebnega dvornega zdravnika Johannesa Kraffta (Johannes Crato von Krafftheim).

Slednji je bil v svojem času pravi zvezdnik učene kulture, svetilnik medicinske znanosti in dvorni zdravnik treh cesarjev - Ferdinanda I., Maksimilijana II. in Rudolfa II., v Wrocłavu je uspešno preganjal celo kugo (Pestordnung, 1553), v zgodovino znanosti se je trajno vpisal s prvim znanim zapisanim obdukcijskim poročilom (skupaj s kirurgom Petrom Sumo, obdukcija cesarja Maksimilijana II., oktober 1576), njegovi zapiski pa so bili tudi eden od virov, ki jih je Johannes Aurifaber uporabljal pri sestavljanju Luthrovih znamenitih "govorov pri mizi« (Colloquia oder Tischreden Doctor Martini Lutheri); Krafft je namreč od 1535. študiral na univerzi v Wittenbergu in bil kar šest let član Luthrovega razširjenega gospodinjstva.

Impulzi za Blahoslavove tekste so, kot pri Primožu Trubarju, prihajali iz vsakdanjega življenja, potreb, stisk in težav njegove cerkve, Blahoslav pa, čeprav humanist, sam pretežno ni bil tvorec novih intelektualnih 
spregledov, konceptov in/ali smeri mišljenja, kot je bil npr. Jan Amos Komenský. Blahoslavova avtorska besedila in editorska podjetja je mogoče kronološko razvrstiti takole:

\section{Avtorska besedila}

1. 1547, v rokopisu: O původu Jednoty bratrské a řádu v ní. Gre za zgodovinopisno-apologetski traktat, v katerem Blahoslav utemeljuje tezo, da je Jednota bratská Božja cerkev; avtor je besedilo formuliral kot kompilacijo obstoječih pisnih virov in ustne tradicije, kot jo je sam poznal;

2. 1550, tisk okoli 1610: Spis o zraku, jak člověk zrakem, to jest viděním a hleděním, sobě nebo jiným, škoditi může. Moralno-etično besedilo;

3. 1555, v rokopisu: Historia hrozného zahřmění Božího, anobrž hromobití strašlivého, vykonaného skrze Antikrista. Zgodovinski vir, ki upoveduje preganjanje, ki so ga češki bratje v Mladi Boleslavi doživeli po smrti svojega zaščitnika, viteza Arnošta Krajířa s Krajka; ${ }^{20}$

4. 1556, v rokopisu: Summa quaedam brevissima collecta ex variis scriptis Fratrum. Besedilna »druga roka« Blahoslavovega literarnega prvenca $O$ původu Jednoty (1547). V njem je Blahoslav napisal očrt zgodovine čeških bratov do srede 16. stoletja in stopil v polemiko s Flacijem Ilirikom zastran izvora čeških bratov, Flacij je namreč v spisu Catalogus testium veritatis (1556) dokazoval, da je Jednota bratrská izpeljanka valdežanov;

5. 1558, v rokopisu: Sepsání o rozdíle Jednoty bratrské od luteriánské. Polemika $\mathrm{z}$ luterani, ki je imela namen, tudi "pro domo sua (delo je polemiziralo $\mathrm{z}$ moravskimi luterani), jasno razločiti češke brate od nemške smeri reformacije;

6. 1558, tisk istega leta in 1569: Musica, to jest Knižka zpěvákưm náležité zprávy v sobě zavírající. Glasbenoteoretični traktat s praktičnimi napotki, ki jih je Blahoslav namenil skladateljem cerkvene himnike in pevcem;

2o Krajíŕi so prišli na Češko s Koroške, glej: Novákova 2010, 10-30. 
7. 1560, v rokopisu: Anvolimator, to jest O rotě milovné. Gre za delo, v katerem je Blahoslav ubesedil svoj pogled, kakšen naj bi bil krščanski odnos med spoloma. Avtor kara tiste posameznike, ki ne zmorejo krotiti lastnega »mesenega poželenja«, zavrača pa tudi tedaj razširjeno stališče, da so češki bratje pravzaprav nadaljevanje adamitov oz. valdežanov;

8. 1561, v rokopisu: O novém kancionále. Seznam pesmi in njihovih avtorjev v češkobratskih kancionalih;

9. 1561, v rokopisu: O vyvolení Božím. Teološka razprava, ki prinaša Blahoslavovo interpretacijo dvajsetega poglavja Evangelija po Mateju;

10. 1563-1565, v rokopisu: Pilné rozjímání, sluší-li Řeči Boží, Čtení svatá a epištoly opovrci a na ně více kázání nečiniti. Reakcija na prizadevanja škofa Jana Avguste, ki je želel iz češkobratske cerkve izvreči vso starejšo cerkveno liturgično tradicijo, vključno s perikopami, ter uvesti novo bogoslužno podobo, ki bi temeljila le na Credu oz. Apostolski veroizpovedi. Blahoslav zato razpravlja o kriterijih izbora beril za nedeljske in praznične Božje službe;

11. 1564, v rokopisu: Apologia pro editione cantionalis nova. Obramba novega češkobratskega kancionala zoper kritiko Martina Žateckega;

12. 1564: prevod Novega testamenta Nový zákon vnově do češtiny přeložený oz. Nový zákon z jazyku řeckého do češtiny přeložený; leta 1568 je bilo delo izdano pod naslovom Nový zákon vnově z jazyku reckého do češtiny přeložený, Secunda editio diligenter. Gre za najpomembnejši Blahoslavov prevod, ki je nastal na podlagi grščine, toda ob upoštevanju sodobnih latinskih, starejših čeških prevodov Novega testamenta ter Luthrove biblije. Blahoslavova Nova zaveza je pozneje v redigirani podobi predstavljala temeljni kamen Kralicke biblije, izvirno pa je izšla s številnimi komentarji, razlagami in konkordancami, leta 1568 pa prvič s filološkimi in kritičnimi komentarji. Oboje je tedaj predstavljalo vrh češke biblicistke;

13. 1564, v rokopisu: Prokázáni světlé toho, že církev svatá a její učitelé nevěřili a nevyznávali o člověčenství Krista Pána, že by bylo nestvořené a neučiněné. Eksegeza Jn 1,14 »Et Verbum caro factum est, et habita- 
vit in nobis: et vidimus gloriam ejus, gloriam quasi unigeniti a Patre plenum gratiae et veritatis. »In Beseda je postala meso in se naselila med nami. Videli smo njeno veličastvo, veličastvo, ki ga ima od Očeta kot edinorojeni Sin, polna milosti in resnice.« Omenjena razprava poleg Blahoslavove jezikovne kompetence odraža predvsem njegov razgled po sodobnem teološkem spisju reformacije;

14. 1567, v rokopisu: Corollarium oz. Filipika proti misomusom (glej zgoraj);

15. 1570-1571, v rokopisu: Vitia concionatorum, to jest Vady kazatelưv. Kompendij praktične cerkvene retorike za začetnike v homiletiki. Blahoslav je skušal v njem popisati napake, ki so jih pridigarji delali med retoričnim actio na prižnici, in svetovati, kako je mogoče narediti bolje oziroma pravilno;

16. 1571: Evangelia, anebo Čtení svatá, kteráž slovou Pašije. Liturgični priročnik, ki vsebuje notirana češka besedila za rabo pri Božji službi predvsem na praznike;

17. 1571, v rokopisu: Gramatika česká. Blahoslavova dopolnitev najpomembnejšega jezikoslovnega dela češkega 16. stoletja. Gramatika česká, po natisu na posestvu Náměsti plemiča Václava Meziř́ččskega 1533. znana tudi kot »náměstska slovnica«, obsega tri dele. Prvi, Orthographia, je delo Beneša Optáta $(\dagger 1559)$ in se ukvarja s pravopisom češkega jezika. Drugi del, Etymologia, je prišel izpod peresa Václava Filomatesa in podrobno popisuje tiste jezikovne pojave, pri katerih imajo češki prevajalci, kadar je jezik izvirnika latinščina, probleme. K tema deloma je Blahoslav napisal obsežno besedilo $\mathrm{z}$ naslovom Přidání některých věcí k Gramatyce české príhodných; tomu kdož chce dobře, totíž vlastně, právě, a ozdobně česky mluviti i psáti užitečných. V njem so artikulirani Blahoslavovi jezikovni, slogovni in prevodni nazori.

\section{Uredniško delo in ekdotika}

1. 1552-: Acta Unitatis Fratrum, to jest Shromáždění pospolné těch věcí, kteréž v Jednotě bratrské a nejvíc v království Českém puosobeny sou 
od léta 1547 až do 1549. Zbirka šteje štirinajst zvezkov in je temeljni vir za zgodovino čeških bratov, vsi zvezki niso uredniško delo Jana Blahoslava, namen celotnega podjetja pa je bil ustvariti »repozitorij« virov, ki naj bi se ohranili za prihodnje generacije čeških bratov, zlasti škofov; Blahoslav je napisal številne komentarje k besedilom, ki so bila uvrščena $\mathrm{v}$ to zbirko;

2. 1560-: Nekrologium. Gre za seznam duhovnikov in pomembnejših članov cerkve, ki je urejen po datumih smrti posameznikov (liber defunctorum) in je tako pomemben zgodovinski vir, kajti prinaša biografske informacije o posameznih pomembnih čeških bratih;

3. 1561: Piesně chval Božských oz. Šamotulský kancionál. Blahoslavova izdaja enega najznamenitejših češkobratskih kancionalov, ki se imenuje po kraju natisa, Szamotułah pri velikopoljskem Poznanu;

4. 1564: Písně duchovní evangelistské. Ponovna izdaja češkobratske pesmarice, tokrat tiskane $\mathrm{v}$ Ivančicah.

5. 1585: Naučení mládencům k službě Kristu a církvi jeho se oddávajícím $v$ Jednotě bratrské. Spis za duhovniški podmladek čeških bratov.

\section{Novi testament Jana Blahoslava}

Najpomembnejše Blahoslavovo delo je prevod Novega testamenta Nový zákon vnově do češtiny přeložený oz. Nový zákon z jazyku řeckého do češtiny přeložený (1564). O jezikovnih kompetencah prevajalca je bilo s filološkimi analizami ugotovljeno, da je znal dobro latinsko in da mu tudi grščina ni bila tuja, o Blahoslavovih jezikovnih zmožnostih na področju hebrejščine pa ni dovolj jasnih virov, da bi bilo mogoče izreči definitivno sodbo, četudi je mogoče misliti, da se je prevajalec zavedal hebrejskega izvora posameznih besedilnih struktur (Heller 2004, 84). Blahoslava je pri prevajanju vodilo poznavanje antičnih in sočasnih refleksij in praks $v$ latinski in češki humanistični književnosti (Just 2007, 56). Prevodni pristopi 16. stoletja so po navadi upoštevali prevod(oslov)no tradicijo starejših obdobij, tj. srednjega veka. Takrat je bil uveljavljen dvoji pogled. Kánonska besedila, ki štela kot norma- 
tivna, in torej nespremenljiva, so praviloma prevajali bolj ali manj dobesedno. Na tak način so običajno prevajali Sveto pismo in liturgična dela, in sicer besedo po besedo, običajno celo $\mathrm{z}$ ohranitvijo besednega reda izvirnika. ${ }^{21}$ Prevajalec se ni ukvarjal s ponovno tekstno konstrukcijo pomena v jeziku prevoda, temveč si je dal opraviti predvsem s posameznimi besedami izvirnika, in to po navadi brez ozira na razlike med strukturama obeh jezikov. Povsem drugače se je postopalo pri prevajanju nekanonskih del. Tam je bil pristop znatno svobodnejši, poudarek pa je bil na prenosu vsebine dela: prevodna interpretacija se je prilagajala ciljni skupini posameznega prevoda. Zato so izvirniki v prevodu pogosto doživljali skrčitve ali širitve, parafraze in spremembo strukture, včasih pa so (p)ostali celo zgolj predloga za samostojno avtorsko aktualizacijo snovi izvirnika $v$ jeziku prevoda. Za rabo načela »non verbum e verbo, sed sensum expimere de sensu« je Blahoslav našel vzorčne, celo programske primere $\mathrm{v}$ češki humanistični književnosti druge polovice 15. in prve polovice 16. stoletja. Tako je češki humanist, prevajalec in izdajatelj Viktorin Kornel ze Všehrd 12. marca $1495 \mathrm{v}$ predgovoru k delu Janeza Zlatousta O popravi padlega zapisal:

Prevajalci iz jezika $v$ jezik prevajajo eni besedo $\mathrm{z}$ besedo in drugi misel $\mathrm{z}$ mislijo. Sam sem v tem prevodu rabil oboje, toda bolj sem prevajal misel z mislijo kot besedo z besedo. Kajti nihče, ki prevaja, ni dolžan prevajati dobesedno, temveč ako izvirno misel z drugim jezikom smiselno in natančno prevede, je storil dovolj. Temu pritrjujeta Horacij in Hieronim. (Kornel [1495] v Jireček 1874, 538)

Podobno se je ob prevajanju Petrarkovega spisa De remediis utriusque fortunae, prevod naj bi nastal okoli leta 1500, izrazil njegov prevajalec $\mathrm{v}$ češčino Jan Češka:

Te knjige [...] so prevedene iz latinščine v češki jezik, kolikor najlepše je to v tem jeziku mogoče. Nekje je prevedno dobesedno, drugje je pomen za češki jezik povzet po besedah, toda brez spremembe smisla. V knjigah poganskih učenjakov se nahaja veliko takega, kar ni mogoče $z$ istimi beseda-

21 Obstajali so tudi drugačni pristopi, prim. Vinkler 2019, 65-85. 
mi izraziti v tujem jeziku. Zato mora prevajalec, ki išče pomen in smisel, pustiti besede ob strani in prevesti le pomen, kot je $\mathrm{v}$ teh knjigah po redu tudi storjeno. (Češka 1982, 31-31).

Toda Blahoslavov prevajalski pristop je vendarle kazal neko mentalno posebnost, ki je imela, kot je misliti, za razvoj češkega jezika in književnosti daljnosežne posledice; vplivala je namreč na celoten idearij zastran knjižne češčine zgodnjega novega veka in kasnejših obdobij. Gre za Blahoslavovo razumevanja samega statusa bibličnega jezika. Temu je prevajalec pripisoval poseben (Heller 2004, 67), slovesni in privzdignjen pomen, ki da mora biti izražen s primerno visokim češkim jezikovnim slogom, brez izrazil, ki so po njegovem določala pogovorno češčino njegove dobe.

Ta svoj razmislek je demonstriral tudi v svoji Gramatiki, in sicer ob analizi izraza ecce v Mt 2,1:

Cum ergo natus esset Iesus in Bethleem Iudaeae in diebus Herodis regis ecce [poudaril J. V.] magi ab oriente venerunt Hierosolymam ... (Vulgata)

KAdar je pak Iesus bil rojen v'Betlehemi, v'Iudoufki desheli, v'zhaffu Erodesha Krajla: Pole, [poudaril J. V.] tedaj fo prifhli Modri od Iutrove deshele v'Ierusalem ... (Dalmatinova biblija, 1584)

Spor, ali pritiče za ecce češki prevod a aj ali a hle, je bil v Blahoslavovem času precej oster. V Dresdenski bibliji (Drážd’anská bible, okoli 1360) je bilo zapisano a aj, v prvi Severýnovi bibliji (1529) pa a hle in tako odtlej dosledno. Blahoslav ni soglašal z Václavom Filomatesom, da bi izraz aj zapopadal izražanje jeze, temveč je menil, da gre za izrazilo nižjega jezikovnega sloga zavoljo socialne strukture govorcev:

$[120 \mathrm{a}]^{22}[\mathrm{~K}]$ ot bi s temi svojimi tovariši nikoli ne slišal drugih Čehov, le pastirje in gnojarje, ki si po poljih drug drugemu vriskajo etc. [...]

[12ob] Predrzno je na vsakem mestu, kjer v latinščini stoji ecce, po češko zapisati hle, in to še v Gospodovem zakonu, ki ni bil v češčino preve-

22 Segmentacija besedila je enaka, kot je v zadnji izdaji Blahoslavovega dela (2015). 
den za to, da bi ga gonjači, ki govorijo po domače, brali na paši, temveč za to, da bi bil na občestvenem zboru bogaboječih ljudi iz različnih stanov kot volja najvišjega cesarja in gospoda vsega stvarstva $z$ veliko resnostjo prebiran in bi v njihovih ušesih zvenel dostojanstveno. Zato ne pritiče prevajalcem besede Božje v prevodu rabiti vseh mogočih lahkih, gostilniških, pastirskih ipd. besedi, temveč le takšne, ki bi mogle razumnim ljudem pripomoči k pobožni resnosti in $\mathrm{k}$ dobremu srcu, takšne, ki bodo pomogle $\mathrm{k}$ pozornosti na tisto, o čemer je govora, ne pa služile za smeh ali spravljale iz prave mere.

[121b] Ali ni neizmerna škoda, da se s takšnimi neprimernimi besedami (pa nimam v mislih le ene, temveč številne njej podobne besede in phrases) in z njihovo nespametno rabo posvinja zakon Gospodov, Gospoda Jezusa in svetih apostolov besede?

Blahoslav se je pri prevajanju opiral na različne vire, toda primarno na grško besedilo (Just 2007, 103) ${ }^{23}$ Odločitev je pojasnil v Gramatiki:

[144a] Zakona Gospodovega v češki jezik ne kaže prevajati samo ex vulgata latina editione in qua plus quam sexcenti loci corrupti sunt etc., sed ex graeco textu; ad fontes [poudaril J. V.] enim reccurendum esse, inter omnes pios et eruditos constat; $\left[{ }^{24}\right]$ dokaz omenjenega glej tudi v papeškem dekretu in obširno pri Avguštinu. $\left[{ }^{25}\right]$ Gotovo je namreč (če bi bilo treba, je mogoče tudi na široko in dovolj temeljito dokazati), da je moč številne besede iz grščine lepše prevesti $\mathrm{v}$ češčino kot $\mathrm{v}$ latinščino ... $\left[{ }^{26}\right]$

$\mathrm{Na}$ navedenem mestu prihajata izrazito v ospredje Blahoslavov humanistični intelektualni format in slednjega temeljni metodološki po-

23 Popis in argumentacijo vseh prevajalskih virov za Blahoslavov Novi testament glej v Just 2007, 103-136.

$24[\mathrm{I}] \mathrm{z}$ latinske izdaje Vulgate, v kateri je več kot šeststo poškodovanih mest, temveč iz grškega teksta; vsem pobožnim in učenim ljudem je namreč znano, da je treba črpati neposredno iz virov[.]

25 Avrelij Avguštin, De doctrina christiana 2.XI.16, 2.XIII.19, 2.XV.22.

26 Slednje je mogoče razumeti tudi kot del jezikovno obrambne strategije, s katero je Blahoslav zlasti v predgovoru Gramatike utrjeval položaj knjižne češčine kot jezika učene kulture napram latinščini, nemščini in celo francoščini (Pražák 1945, 33-4). 
stulat študija primarnih virov v izvirnem jeziku - ad fontes. Ta je bil tedaj že vsaj dobro stoletje, od Adnotationes in Novum Testamentum Lorenza Valle (1444, pod naslovom In Novum testamentum annotationes $^{27}$ izdal Erazem Rotterdamski, 1505), del standardnega intelektualnega repertorija tudi pri prevajanju Svetega pisma. Omenjeno stališče Blahoslava po metodološki prevajalski plati povezuje s Primožem Trubarjem, ki je, črpajoč iz sorodnih intelektualnih tokov - iz krščanskega humanizma -, že pri prevajanju Evangelija po Mateju (1555) v predgovor zapisal:

$\mathrm{H}$ drugimu vom poveimo, de mi v le-tim našim prevračenu smo veden imeili pred sebo ta pravi studenic tiga Noviga testamenta, kir ie gerški pissan; raven tiga smo mi tudi gledali na prevračene tih novih inu starih vučenikov, kateri so ta Nov testament iz tiga gerskiga iezica v ta latinski, nemški inu v laški preobernili, ner več pag na Erazmov Roterodamov Nov testament, h timu so nom nega Annotationes sylnu pomagale. (Trubar [1555] v Vinkler 2017, 17-8)

Ob bibličnem prevajanju je imel Blahoslav pred očmi predvsem sistematično in praktično teološke razloge za izbor besedja in izrazil. Biblično besedilo v češčini je estetiziral in intelektualiziral, z zavestno odločitvijo za zahtevnejšo, estetsko izbrano jezikovno rabo, ki se je znatno, in s stoletji čedalje bolj, razlikovala od običajne govorjene češčine pa je, ker je postal njegov Novi testament $\mathrm{v}$ redakciji temeljni kamen Kralicke biblije (Bible kralická, 1579-1593), le-ta pa podstava baročne knjižne češčine in nato kot »biblijščina« v 19. stoletju z Josefom Jungmannom obnovljene knjižne češčine, temeljno vplival na podobo češkega jezika in komunikacije vse do sodobnosti. In je tako vzpostavil tudi dierezo med knjižno (spisovná čeština) in govorjeno (obecná čeština) češčino, ki v izrazju in rabi vztraja do danes (Heller 2004, 88-89).

Toda pred tem se je zgodil usodni prelom. Poleg intelektualnega polja so namreč češki bratje plemiške krvi v zadnjih desetletjih »stoletja reformacije« živahno zaigrali tudi na deželni in državni politični ša-

27 Omenjeno delo je kot pomembno pomagalo izrecno izpostavil tudi Primož Trubar pri prevajanju Evangelija po Mateju (Trubar [1555] v Vinkler 2017, 18). 
hovnici. Toda to je bila za maloštevilno cerkev, ki je ves čas nihala med legitimnostjo reformacijskega prepričanja in podtaljem, (ne)legalnostjo ter preganjanjem s strani dežele in države, igra z ognjem. Ta se je na koncu iztekla v vsespošno kataklizmo tridesetletne vojne. In o tem bo tekla beseda v naslednji razpravi o bitju in nehanju čeških bratov.

\section{VIRI IN LITERATURA}

\section{VIRI}

Blahoslav, Jan. 1861. »Blahoslavova filipika proti nepřátelům vzdělání vy̌̌šího v Jednotě bratské.« Časopis českého Musea: 372-81.

---. 2010. Čtyři menši spisy. Ur. Mirek Čejka. https://mirekcejkaa.wordpress. com/2010/12/17/jan-blahoslavctyri-mensi-spisy/

---. 2015. Gramatika česká (1571). Ur. Mirek Čejka in Dušan Šlosar. https://mirekcejkaa.files.wordpress.com/2015/o1/grammatica-restituta.docx

Češka, Jan. 1982. Řeči a naučení hlubokých mudrců. Ur. Milada Nedvědová. Praga: Odeon.

Hlaváček, Ivan, ur. 1981. Ze zprav a kronik doby husitské. Praga: Svoboda.

Jireček, Hermenegild, ur. 1874. M. Viktorina ze Všehrd o právích země České knihy devatery. Praga. https://archive.org/details/mviktorinazevehoovegoog

Molnár, Amedeo, Noemi Rejchrtová in Luděk Rejchrt, ur. 1977. Slovem obnovená. Čtení o reformaci. Praga: Kalich.

Vinkler, Jonatan, ur. 2005. Zbrana dela Primoža Trubarja III. Ljubljana: Rokus.

---, ur. 2017. Zbrana dela Primoža Trubarja XII. Ljubljana: Pedagoški inštitut. DOI: https://www.doi.org/10.32320/978-961-270-269-4

Vrečko, Edvard, ur. 2011. Zbrana dela Primoža Trubarja XI. Ljubljana: Pedagoški inštitut. DOI: https://www.doi.org/10.32320/978-961-270-098-0

Vrečko, Edvard, in Fanika Krajnc-Vrečko, ur. 2015.Zbrana dela Primoža TrubarjaX.Ljubljana: Pedagoški inštitut. DOI: https://www.doi.org/10.32320/978-961-270-230-4

\section{LITERATURA}

Breznik, Anton. 1982. Jezikoslovne razprave. Ljubljana: Slovenska matica. 
Čejka, Mirek, in Dušan Šlosar, 2015. „Úvod k poslední verzi edice Blahoslavovy Grammatiky.» https://mirekcejkaa.wordpress.com/uvod-k-posledni-verzi-edice -blahoslavovy-grammatiky/

Eisenstein, Elisabeth L. 1979. The Printing Press as an Agent of Change: Communication and Cultural Transformations of Early-Modern Europe 1-2. Cambridge: Cambridge Universsity Press.

Forst, Vladimir, et al., ur. 1985. Lexikon české literatury. Osobnosti, díla, instituce. Díl 1. A - G. Praga: Academia.

Gillet, Johann Franz Albert. 186o. Crato von Crafftheim und seine Freunde. Ein Beitrag zur Kirchengeschichte nach handschriftlichen Quellen. Frankfurt ob Majni: Brönner. https://archive.org/details/bub_gb_qRRBAAAAcAAJ/page/n3

Heller, Jan M. 2004. "Blahoslavûv překlad Nového zákona.« Listy filologické CXXVI (1-2): 66-92.

Just, Jiř́i. 2007. Biblický humanismus Jana Blahoslava. Disertační prace. Praga: Univerzita Karlova v Praze, Evangelická teologická fakulta. https://is.cuni.cz/webapps/ zzp/detail/18388/

»Jan Blahoslav.«https://cs.wikipedia.org/wiki/Jan_Blahoslav ${ }^{28}$

Kohler, Alfred. 2017. Ferdinand I. (1503-1564). Knižze, král a císař. Češke Budejovice: Veduta.

Lambert, Malcolm. 200o. Středověká hereze. Praga: Argo.

Meister.1894.»'Trotzendorf',eigenthlich ValentinFriedland.«VAllgemeineDeutscheBiographie 38: 661-67. Spletna verzija. https://www.deutsche-biographie.de/pnd12113 4245.html\#adbcontent

Molnár, Amedeo. 1971. »Blahoslavovy náběhy k teologii dějin.» Křestanská revue XXXVIII (9): 208-14.

---. 1991. Valdenští. Evropský rozměr jejich vzdoru. Praga: Kalich.

Novaková, Stanislava. 2010. Krajírové z Krajku. Z Korutan do zemí České koruny. Češke Budejovice: Veduta.

Plett, Heinrich F., ur. 1993. Renaissance-Rhetorik - Rhenaissance Rhetoric. Berlin in New York: Walter de Gruyter.

Pražák, Albert. 1945. Národ se bránil. Obrany národa a jazyka českého od nejstarších dob po prítomnost. Praga: Sfinx, Bohumil Janda.

Říčan, Rudolf. 1956. »Dějiny Jednoty v přehledu.«V Jednota bratrská, 1457-1957: Sborník k pětistému výročí založení, ur. Rudolf Říčan et al., 11-108. Praga: Kalich.

28 Seznam Blahoslavovih del je zavoljo preglednosti za slovenskega bralca po zadevnem viru povzet tudi v pričujoči razpravi. 


\section{JONATAN VINKLER}

Říčan, Rudolf, et al., ur. 1956. Jednota bratrská, 1457-1957: Sborník k pĕtistému výročí založení. Praga: Kalich.

Sedlák, Jan. 1996. M. Jan Hus. 2. vydání. Olomouc: Matice cyrilometodějská.

Svatoš, Martin. 1995. Dějiny Univerzity Karlovy I: 1347/48-1622. Praga: Univerzita Karlova, Vydavatelství Karolinum.

Škarka, Antonín. 1958. »Jan Blahoslav. Literárněhistorický portrét, připravná studie k Dějinám české literatury.« Česká literatura 6 (2): 150-76.

Šmahel, František. 1996. Husitská revoluce. 2: Kořeny české reformace. Praga: Univerzita Karlova, Karolinum.

Vinkler, Jonatan. 2011. »Primož Trubar in 'nepravoverne' smeri reformacije v slovenskem slovstvu 16. stoletja: prekrščevalci.« V: Jeziki, identitete, pripadnosti med središč in obrobji: v počastitev 50o. obletnice rojstva Primoža Trubarja, ur. Kozma Ahačič in Petra Testen, 99-108. Ljubljana: Založba ZRC, ZRC SAZU.

---. 2015. »Tekst in kontekst: De Ecclesia - fatalno besedilo M. Jana Husa in njegovo zgodovinsko 'sobesedilo'.« Stati inu obstati: revija za vprašanja protestantizma 15 (21-22): 12-40

---. 2018. „Češki bratje - 560 let. 2, Po Luthrovem nastopu - med reformo in politiko.« Stati inu obstati: revija za vprašanja protestantizma 18 (28): 83-106.

---. 2019. »Trubarjeva biblija v kulturnozgodovinskem kontekstu - med prevajanjem in pisanjem." Stati inu obstati: revija za vprašanja protestantizma 19 (29): 59-87.

Winter, Zikmund. 1897. Děje vysokých škol pražských od secessí národů až do Bílé Hory (1409-1622). Praga: Česká akademie císaře Františka Josefa. https://archive.org/ details/deje_vysokych_skol_prazskych 